\title{
Tatar Çölü ve Gizli Emir Romanlarında Bir Varoluș Biçimi Olarak Umut ve Umutsuzluk Paradoksu
}

\author{
MURAT KACIROĞLU*
}

\begin{abstract}
ÖZ
Dino Buzatti'nin Tatar Çölü ve Melih Cevdet Anday'ın Gizli Emir romanları, farklı dil ve edebiyatların ürünleri olmalarına rağmen, insanın dünyadaki varoluşsal konumunu umut ve umutsuzluk duygusunun evrensel nitelikleri bağlamında ele alan metinler olarak değerlendirilebilir. Bu iki romanda umut, insanın dünyadaki bütün eylemlerine yön veren temel duygu olarak ortaya konurken, aynı zamanda bu duygunun diyalektik biçimde umutsuzluğu belirleyen yönüne dikkat çekilir. Bu bağlamda umut ve umutsuzluğun paradoksal biçimde insanın varlık oluşunun iki yönünü oluşturduğunu vurgulayan romancılar, yarattıkları roman kahramanlarının hayatlarını bu paradoksun belirlediği gerilim çerçevesinde anlatmaya çalışırlar. Bu gerilim ise "bekleme" ediminde kendini gösterir. Bu edimin yöneldiği umudun gerçekleşip gerçekleşmemesinden çok, doğrudan eylemin kendisinin önemli olduğuna dikkat çeken romancılar, insanın dünyadaki varlığ1nın bu eylemi algılarken takındıkları tavırla ilişkili olduğunu ima ederler. "Bekleme" yi varoluşsal problemin kaynağı olarak görebilen insanın kendi varlığının bilincine ulaşabileceğini düşünen Buzatti ve Anday, roman türünün imkânları çerçevesinde konuyu felsefî bir boyutta ele almışlardır.
\end{abstract}

Anahtar sözcükler: Tatar Çölü, Gizli Emir, varlık, umut, umutsuzluk, bekleme

Wodern İtalyan roman ve öykücülüğünün önde gelen isimlerinden biri olan Dino Buzatti'nin 1940 yilında yayımlanan ve 1991 yılında Türkçeye çevrilen Tatar Çölü adlı romanıyla, Melih Cevdet Anday'ın 1970 yılında yayımlanan Gizli Emir romanı, varoluşçu bir bakış açısıyla insanın

Doç. Dr., Bozok Üniversitesi, Türk Dili ve Edebiyatı Bölümü/YOZGAT

E-posta: murat.kaciroglu@bozok.edu.tr 
"dünyada-olmaya-bırakılmışlı̆̆ına" anlam kazandıran "bekleme"nin -umarak beklenti içinde olmanın (Heidegger 2011a: 35)- sonsuz bir çileye dönüşmesini anlatan romanlar olarak dikkat çeker. Her iki romanda insanın umut ve umutsuzluk paradoksu içinde savrulan varlık biçimi, bekleme ediminin anlamsızlığı merkeze alınarak anlatılır. Buzatti ve Anday, insanın dünyadaki varlığını belirleyen ve varoluşunu koşullayan şartların dışına çıkmasının imkânsızlığını ontolojik bir problem olarak ele alırlar. Romanlarda kahramanların eylem ve davranışlarına yön veren şartlar, onların varlık biçimlerini belirleyen ve Martin Heidegger'in insanın ontolojik durumu olarak gördüğü "dünyaya atılmışlı̆̆ın" yani varlık-içinde-olma durumunun farkına varılması şeklindeki görüşüyle ilişki kurulabilecek biçimde anlatılmıştır (Çüçen 2012: 120). Bu bağlamda Tatar Çölü ve Gizli Emir, insanın varoluş durumunu yine Heidegger' in deyimiyle "Dasein" ın yani varlığın kendisi için bir problem olduğunu gören, bir varolan olarak kendi varlığını icrâ ederken bizatihi kendi varlığını "mesele" eden bireyin trajedisini umut ve umutsuzluk paradoksu içinde sunan romanlardır (2011b: 12).

Tatar Çölü, varoluşun anlamını sorgulayan ve okuru kendi yazgısı içinde düşünmeye iten (Yılmaz 2011: 30) bir roman olarak askerî okuldan yeni mezun Teğmen Giovanni Drogo'nun bir eylül sabahı ilk görev yeri olan ve Kuzey Krallığı'nın sınırında bulunan Bastiani Kalesi'ne gitmek için evinden ayrılmasıyla başlar ve yaklaşık otuz yıl kaldığı kalede hastalanıp evine dönüş yolunda bir han odasında ölümü beklerken son bulur. Bastiani Kalesi'ne sadece dört ay kalmak düşüncesiyle gelen Drogo, bir tarafinda dik kayalıkların ve dağların, diğer tarafında Kuzey Krallı̆̆ı'na ait uçsuz bucaksız Tatar çölünün bulunduğu bu yerde diğer askerler gibi kuzeyden gelecek düşmanları bekler ve bu bekleyiş otuz yıl sürer. Drogo'nun beklediği savaş, otuz yılın sonunda bir han odasında ölümü beklediği zaman başlar.

Distopik bir roman özelliği gösteren Gizli Emir'de ise belirsiz bir zaman diliminde ve adı verilmeyen bir kentte, ne zaman başladığı bilinmeyen anarşi ve kaos ortamının içinde yaşayan insanların hayatlarından kesitler anlatılır. "Yengeç", "Atmaca" ve "Baykuş" adı verilen çetelerin yarattığı karmaşayı önlemek adına iktidarı temsil eden AYOT (Asayişi Yerleştirme Olağanüstü Teşkilatı), halk ve aydınlar üzerinde büyük bir baskı ve sindirme politikası yürütmektedir. Romanın aydın kahramanları başta Heykeltıraş Nizam, Ressam Macid, Başyazar Kutsi, Siyasetçi Ahmet, Aktör Bilal, Ozan Kadri olmak üzere bütün halk, AYOT'un yürüttüğü sıkıyönetim uygulamalarına son verecek olan "gizli emir"in gelmesini beklerler. Olayların ne zaman başladığ1 bilinmediği gibi, gizli emrin ilk defa ne zaman duyulduğu, nasıl ve kim tarafından gönderileceğinin de bilinmediği bu ortamda, bütün kahramanların bilinçleri bu emrin gelmesiyle ilgili söylenti ve beklentiler üzerinde şekillen- 
miştir. Sadece bilinçleri değil, bütün değer yargıları ve inançları gizli emri beklemekle oluşmuştur.

Tatar Çölü ve Gizli Emir, umudu ve onun gerçekleşmesini beklemeyi, insanın bir varoluş durumu veya problemi olarak ele alır. Bu iki romanda bekleme ediminin umut/umutsuzluk paradoksu içinde bir varoluş problemi olarak nasıl ele alındığı karşılaştırmalı biçimde incelenecektir.

\section{1. İnsan ve Dünya: Bir Yazgıya Teslim Olmak}

Heidegger, insanın varlık olarak en önemli özelliğinin mekânsallık olduğunu söyler. İnsanın mekânsallığı, dünya-içinde-olmak şeklinde ortaya çıkan bir ilişkiler bütünüdür (2011b: 56). Bu ilişkiler bütününü anlamak ve onun bilincine varmak, varoluşun en temel özelliğidir. Heidegger, insanın (varlığının bilincine varan Dasein’ın) dünya-içinde-var-olmaklığının var-olmanın belirli tarzları içine saçılmış hatta parçalanmış biçimde geliştiğini savunur. $\mathrm{Bu}$ var-olma tarzlarını bir şeyle uğraşıyor olmak, bir şeyden vazgeçmek ya da bir şeyi kaybetmek, girişimde bulunmak, istediğini yerine getirmek, bilgi almak, soruşturmak, gözetlemek, tartışmak şeklinde sıralar (2011: 58-59). Bu anlamda, Tatar Çölü ndeki Drogo ve Gizli Emir'deki aydın kahramanlar, dünyada-var-olmayı, umuda yönelik bir beklemeyle birlikte tecrübe ederler. $\mathrm{Bu}$ bekleme, insanın dünyadaki varlık durumu ve onun mekânsal oluşuyla ilgilidir, çünkü dünya, Heidegger'in ifade ettiği biçimiyle varlık belirlenimlerinin bir a priori'sidir. Bu ise, dünya-içinde-var-olmadır (2011b: 55). Varolmanın bu boyutu dünya-içine-atılmış bir varlık olmayla anlam kazanır. Dasein, kendi proje ve plânlarına doğru ilerlerken, aynı zamanda bu atılmışlığı, onun düşüşünü veya eksikliğini de ortaya koyar. Düşüş veya eksiklik bir olumsuzluk değil, otantik varoluşa gidiş demektir. Düşüş daha önce bulunduğu bir yerden olmadığı gibi, Dasein’ın düşüşü kendini atılmış olarak bulduğu dünyadaki bir tür varoluşsal tarzdır (Çüçen 2012: 121). Hem Tatar Çölünnde hem de Gizli Emir'de kahramanların dünya içindeki varolma tarzları, böyle bir atılmışlığın veya düşüşün yaşanışı olarak ortaya çıkar.

Tatar Cölü ve Gizli Emir'in kahramanlarının varlıkları bu atılmışlı̆ı̆n belirlediği şartlar içinde anlam kazanmaktadır çünkü Dasein'ın temel yazgısı, kendini dünya içindeki varlıklarla rastlantısal bulmasıdır (Çüçen 2012: 62). Drogo'yu kaleye sürükleyen şey, sadece amirlerinin tasarısı olarak mı değerlendirilmelidir? Bastiani Kalesi'nin sakinleriyle Gizli Emir'deki insanlar, adı verilmeyen kentte var-kılan dünyada-oluşun rastlantısallığı olarak düşünülebilir. Drogo'nun ilk görev yeri olarak geldiği Bastiani Kalesi, simgesel olarak mekânsallığı işaret eden dünyanın metaforik hâlidir. Bu hâl aynı zamanda hem Drogo hem de kaledeki diğer askerler için bir yazgının da adıdır. Bu 
yazg1, mekânın/dünyanın belirlediği bir yazgıdır. İnsanın mekâna bağl11ığı onun yazgisını da belirleyen şeydir. Ortega y Gasset, yaşamayı, dünya-içinde-varolmayı bir ortamın çaresiz tutsağı olmak biçiminde nitelendirirken, insanın mekâna ve dünyaya göre şekillenen yazgısını vurgular (2011: 9).

Drogo kaleye gelişiyle birlikte kendini ortamın yazgısına teslim etmiş olur. Yolda karşılaştığı Yüzbaşı Ortiz'le tanıştığı an, kalenin belirlediği yazgıya teslim oluş anı olarak verilir. "[Yüzbaşı Ortiz'in] elini sıktığında Drogo birden kalenin dünyasına girdiğini duyumsadı. Henüz ilk bağlantıydı, daha sonra, kendisini oraya tamamen zincirleyecek sayısız ve her türden başka bağlantılar olacaktı" (Buzatti 2014: 13). Drogo'nun yazgısı olacak kale, insanın evreni olarak onu bütünüyle kuşatmış gibidir., Bu kuşatmanın en belirgin yanı ise, sonsuz bir sıradanlık biçiminde işleyen gündelik hayattır. Öyle ki, on sekiz yıldır burada görev yapan Yüzbaşı Ortiz, kalenin yüz yıl önce nasılsa, şimdi de aynı olduğunu "ölü bir sınır ucu"nda geçen yıllar boyunca hiçbir şeyin değişmediğini söyler (2014: 17). Kale, buraya kısa bir zaman kalmak üzere gelen tüm asker ve subayları kendi evreni içine hapseden ve onları kendi sıradanl1ğına dönüştüren bir yer olarak, insanın varoluşsal anlamdaki mekânsallığını veya dünyaya atılmışlı̆̆ını vurgular. Başka bir deyişle, insanın hem evi hem hapishanesi olur (Tanribilir 2012: 45).

Bastiani Kalesi'nin insanın yazgısını belirlediğinin kanıtlarından biri de Drogo'nun kaleye geldikten kısa bir süre sonra tanıdığı Terzi Prosdocimo'dur. $\mathrm{O}$ da Drogo gibi kısa bir süre kalma düşüncesiyle oraya gelmiştir. Ancak kale, onun bütün varlığını kuşatmış ve on beş yıl burada kalmasına neden olmuştur. Bu ironik durum, terzinin yanında çalışan çırakların söyledikleriyle verilir ve bunun kalenin içinde yaşayanların asla kurtulamadıkları ölümcül bir hastalık olduğu vurgulanır: "Halbuki, asla buradan gitmeyecek... O, alay komutanı albay ve daha pek çoğu ölene değin burada kalacaklar; bu bir tür hastalık, dikkatli olun teğmenim, siz ki yenisiniz henüz gelmişsiniz, daha vakit varken dikkat edin" (2014: 54). İnsanı kendisine dönüştüren ve bu dönüşüm süreci içinde bütün eylemleri anlamsızlaştıran bir varlık ortamı olan kale, Drogo'nun ilk ve son görev yeri olur.

Bastiani Kalesi'nin komutanı Albay Filimore da aynı yazgının esiri durumundadır. Kalede kaç yıl geçirdiğini unutan komutan, yıllar boyu kuzeyden gelecek düşmanla savaşmayı beklemiş ve bu beklenti içinde sonuçsuz ve saçma bir döngünün içine hapsolmuştur. Her gün aynı ritm ve hızda devam eden nöbet değişimleri, içtimalar, yemek ve dinlenme saatleri, her türlü eylem aynı sıradanlıkla sürüp gitmektedir. Drogo bu durumu kaleye geldikten yaklaşık dört ay sonra şu sözlerle anlatır: "[G]erçekten de öyleydi. Dün gibi geliyordu ama zaman geçmişti, o hareketsiz herkes için aynı, duran yani ne daha mutlu olanlar için daha yavaş, ne de talihsizler için daha hızlı olmayan 
ritmiyle geçiyordu" (2014: 65). Bütün insanlar ve hatta yaşam, iki y1lın sonunda Drogo için sadece alışkanlık hâline gelir:

Arkadaşları da bir alışkanlık hâline gelmişti: Artık onları öylesine iyi tanıyordu ki, en incelikli imalarına bile dikkatsizce yakalanmıyor, karşlık veriyordu, akşamları uzun uzun, geçen zamanla birlikte sonsuz önem kazanan şehir konusunda konuşuyorlard. Rahat ve lezzetli yemekler, subay yemekhanesinin gece gündüz yanan şöminesi; ve Geronimo adında sevimli bir çocuk olan, giderek özel zevklerini daha iyi öğrenmeye başlayan emirerinin aceleciliği, hep alışkanlık haline gelmişti. (2014: 72)

Drogo'nun içine düştüğü alışkanlıklarla arasında öyle derin ilişkiler kurulur ki, bu alışkanlıklar neredeyse onun varlığının merkezi hâline gelirler. İnsan, içine atıldığ dünyanın olgusallığ 1 veya bunu doğuran mekânsallığın içinde, bunların kendisine dönüşür. Heidegger'in vurguladığ gibi ontolojik bakımdan doğru biçimde anlaşılmış özne, aslî anlamda mekânsaldır. Dasein, mekânsal olduğu içindir ki mekân kendini bir a priori olarak gösterebilmektedir (2011: 17).

Tatar Cölünnde Drogo'nun yazgısını belirleyen mekânsallık, Gizli Emir romanındaki kahramanların hayatları üzerinde de aynı belirleyici güce sahiptir. AYOT’un yönettiği şehirde, ne zaman başladığı belli olmayan bir düzensizlik ve kargaşanın içinde yaşayan insanlar, kendilerini çevreleyen ortamın birer parçası hâline gelmişlerdir. Öyle ki, bu düzensizlik ve kargaşa onlar için artık kanıksanmış bir yazgıya dönüşmüştür. Kente hâkim olan AYOT’un insanları kontrol altında tutmak için yönlendirdiği akıl dışı uygulamalar, gruplar arasında her gün farklı biçimde ortaya çıkan çatı̧̧malar, insanlar üzerinde derin bir baskı yaratmıştır. Ancak bu baskılar artık gündelik hayatın basit birer alışkanlığına dönüşmüştür. İnsanların yaşananlar karşısındaki tepkisizliği "bir heykeltıraşın ya da bir ressamın karşısında poz veren modeller[in]" cansızlığına benzer şekildedir (Anday 2011: 91). Sürekli bildiriler yayımlayarak insanların hayatlarını yönlendiren AYOT'un bazı bildirileri ironik bir şekilde birbirleriyle çelişir. Ancak bu çelişkiler bile insanlar üzerinde bir tepki yaratmaz. Sorunların çözülmesi amacıyla yayımlanan bildiriler, aksine onları daha da çözümsüz hâle getirir. Bu durumun, Bastiani Kalesi’nde yaşayanların hayatlarına yön veren alı̧̧kanlıkların uyutucu etkisiyle aynı olduğu şu cümlelerde açıkça görülür:

Artık hiçbir kentli, nasıl davrandığında ceza göreceğini, nasıl davranıldığında görmeyeceğini bilemiyordu. Böylece de herkes suçlu duruma düşüyordu ister istemez. Bu duruma alı̧̧1dığı için de kimse hakkını aramaya kalkmıyordu. Öyle ki, AYOT'a çağrılanlar ya da AYOT'ça tutuklananlar, çoğun, çağrılma ve tutuklanma nedenlerini sormuyorlardı. 
Ortada tümden suçlu bir kent halkı ve sürekli olarak onu yargılayan ve cezalandiran bir AYOT vard1. (2011: 124-125)

Kentte yaşayan insanların AYOT'un baskıları karşısındaki tepkisizliğine karş11ık, bir avuç sanatçı ve aydın bilinçli, çoğu defa da bilinçsiz tepkiler geliştirir. Ancak tepkiler de kendi içinde gündelik hayatın sıradan birer davranış modeline dönüşmekten kurtulamaz.

\section{Bir Varolma Biçimi: Umut ve Bekleme}

Tatar Çölü ve Gizli Emir'de kahramanların yazgılarını belirleyen ortamın yarattığ1 sıkıcı alışkanlığa karşı, onlar için bir çeşit varoluş biçimine dönüşen bekleme ve bu edimin doğası gereği yöneldiği umut, her iki romanın temel meselesi olarak ortaya çıkmaktadır. Ancak bekleme edimi, roman kahramanlarının yaşadıkları ortam ve bunun yarattı̆̆ 1 yazgı, hissettikleri bunalımın artmasına neden olur, çünkü umut ve bekleme dünyada-olmaya-bırakılmışli$\breve{g}$ ın doğurduğu varoluş işkencesini daha da ağırlaştırır. Nietzsche, İnsanca Pek İnsanca adlı kitabında umudun en büyük kötülük olduğunu, çünkü 1stırab1 uzattığını söyler (2010: 78). Nietzsche'nin hayatın ve insanın bu dünyadaki eylemlerinin anlamına yönelik ortaya koyduğu bu düşünce, varoluşsal açıdan insanın bu dünyadaki varlık biçimine yönelik derin bir kuşkunun ve açmazın da yansımasidır.

Erich Fromm'a göre "umut etme" bir varolma biçimidir (2012: 26). Bununla birlikte umudun kırılması insan varlığının belirleyici bir özelliğidir (2012: 34). Tatar Çölü nde Drogo’yu, sadece dört ay kalma düşüncesiyle geldiği Bastiani Kalesi'nde yaklaşık otuz yıl tutan duygu, varoluşunun anlamı olan bu umut duygusudur. Kaleye geldiğinin üçüncü ayında doktorun verdiği raporla kente dönme şansını elde ettiği hâlde, onu kalede tutan sadece "kahramanca bir yaklaşım” mıdır? Yoksa "alışkanlıkların uyuşukluğu”nun (Buzatti 2014: 71) yarattığı bir çaresizlik ve hiçlik duygusu mudur? Drogo, bu paradoksun anlamına kaleden ayrılmamaya karar verdikten birkaç ay sonra ulaşır ve kaleden gidişini engelleyen şeylerin farkına varır:

Drogo, bir isteğin gidişini engellemesiyle kalmaya karar verdi, ama bir şey daha vardı: Kahramanca bir yaklaşım, böylesi önemli bir kararın alınması için yeterli olmayabilirdi. Şu an için soylu ve iyi niyetli bir davranışta bulunduğunu düşünmekte, kendisini umduğundan daha üstün bularak şaşırmaktadır. Ancak birkaç ay sonra, geriye dönüp de baktı̆̆ında, kendisini kaleye bağlayan zavallı şeylerin farkına varacaktır. (2014: 71) 
Drogo'yu kaleye bağlayan "zavallı şeyler" aslında kendi varoluşunu sağlayan, onu insan yapan umududur. "[A]skere özgü kibir”, "her günkü davranışlara duyulan evcil aşk", "görevin monoton ritmi"(2014: 71) onun kaledeki varlığ1$\mathrm{n} 1$ anlamlı kilar. Drogo'nun yazgisını belirleyen umut ise ancak bunlarla belirlenen yolculuğudur. Bu yolculukta umut, insanda varoluş duygusu uyandırır (Koç 2014: 104). Drogo'yla birlikte kaledeki herkes aynı varoluş duygusunun içinde nefes alır. Kalenin kuzeyindeki çölden gelecek düşmanla yapılacak savaşı beklemek, yaşamsal bir güç hâline gelmiştir. Ancak bu umut/bekleme kaledekiler için itiraf edilmesi zor, herkesin birbirinden sakladığı bir duygudur. Sanki kaledekiler, bilinçaltlarına attıkları ve ortaya çıkmasını olağanüstü bir olay olarak görecekleri veya kaledeki sıradan hayatı bozacak bir gelişmeyi beklemektedir. Bu olay ilk defa, Drogo'nun kaleden kırk beş dakika uzaktaki tabyada nöbette olduğu bir gün gerçekleşir. Drogo, Tatar çölünü gözetlerken hareket eden siyah bir nokta görür. Bu görüntü tabyadaki bütün askerler arasında büyük bir heyecana neden olur. Karanlık çöktükten sonra karartının tabyaya yaklaşması, bu heyecanı dayanılmaz hâle getirir. Ancak kısa bir süre sonra bu karartının başıboş bırakılmış bir at olduğu anlaşılır. Buna rağmen at, "kurulu düzeni alt üst" eder. " $[\mathrm{K}]$ endisiyle birlikte kuzeye ilişkin eski efsaneleri, Tatarları, muharebeleri de geri” getirir ve “[m]antıksız varlığıyla tüm çölü” doldurur (2014: 91). Tabyaya yaklaşan atı yakalamak için kimseye haber vermeden kaleden ayrılan Er Lazzari tabyaya dönüşte parolayı bilemediği için nöbetçi tarafindan vurularak öldürülür. Kaleden duyulan bu silah sesinin yarattığ 1 etkiyi şu cümlelerle aktarır:

Bu silah sesi kaledekiler için umudun sesi gibidir. Herkesin birbirinden sakladığ umudun sesidir. Birkaç er dışında hiç kimse, hepsinin yüreğinde yatan o sözcüğü telaffuz etmemektedir. Subaylar bunu söylememeyi tercih etmektedir, çünkü bu onların umududur. Kalenin surları Tatarlar yüzünden inşa edilmiştir, yaşamlarının büyük bir bölümünü, burada onlar yüzünden geçirmektedirler, nöbetçiler, Tatarlar yüzünden gece gündüz makine gibi yürümektedirler. Ve bazıları bu umudu her sabah yeni bir inançla beslemekte, bazıları onu, benliklerinin en gizli köşesinde saklamakta, bazıları ise bu umuda sahip olup olmadıklarını bile bilmemekte, onu yitirdiklerini zannetmektedir. (2014: 99-100)

Tatarlarla savaşma umudu kaledeki yüzyıllık anlamsız hayatı belki anlamlı kılan tek şeydir. Umut etmek ve beklemek Drogo'nun günlük davranışlarından biri hâline dönüşür. Onun için güneşin battığı saatler umut saatleridir. Uzun nöbet saatleri sırasında sürekli hayaller kuran Drogo, "her seferinde biraz daha zenginleşen kahramanlık hülyalarına" dalar (2014: 86). Kalenin Tatar istilasına uğradığını, bu istilaya karşı arkadaşlarıyla günlerce kahramanca savaştı̆̆ını, kendisinin de yaralandığı bir anda takviye güçlerin gelmesiyle Tatarları yenilgiye uğrattıklarını, sonrasında kahramanlığından 
dolayı kral tarafından onurlandırıldığını düşleyen Drogo'nun arzusu, aslında umut ediminin ütopik işlevinin taşıdığı pozitiflikten uzak bir bilincin/bilinçsizliğin yansımasıdır. Umudun ütopik işlevi kendisi için umulmayan tarzda henüz-var-olmayana sahiptir ve reel bir mümkünü varsayar. Buna karşın ham hayal, hayalperestlik, yalın hüsnü kuruntu yalnızca boş-imkân etrafında döner (Çilingir 2003: 94). Ernst Bloch, umudun eyleme yansıyan içeriğinin bilinçli olarak aydınlanmış, bilerek açılanmış pozitif ütopik işlev olduğunu söyler (2013: 186). Ancak Drogo'nun umudu bu anlamda negatif ütopik bir işleve sahiptir, çünkü umudunu gerçekleştirebileceği eylemleri sergilemekten uzaktır. Öncelikle Bastiani Kalesi onun kahramanlık arzularını karşılayacak bir kaderin yeri değildir. Burayı bırakıp arzularını gerçekleştirecek bir göreve gitme şansı olduğu hâlde bunu kullanmayan Drogo'nun irade zaafı yıkıcı bir yazgiya kurban gitmesine neden olur.

Bastiani Kalesi'ndeki diğer insanlar da aynı yıkıcı yazgıyı yaşamaktan kendilerini kurtaramazlar. Onlar için umut değil de ona yönelen bekleme önemlidir. Daha da ötesi, bu bekleyiş onlar için bir nevi kendini gerçekleştirme biçimidir ve kendi varlıklarının koşulu olmuştur. Gabriel Marcel, insanın bu varlıksal biçimine "homo viator" (gezgin varlık) adını verir (1951: 64). Drogo da bir homo viator olarak dünyanın metaforu olan bu kaleye gelen ve buradaki yaşamsal yolculuğunu ontolojik bir boyutta deneyimleyen bir kahramandır. Gerçekten de o bir umut adamıdır. Sadece kuzeyden gelecek Tatar ordularını beklemekle kalmaz, kaleden ayrıldıktan sonra yaşayacağı hayat için de ayrı umutları vardır. $\mathrm{O}$, umudun yöneldiği nesneden/nesnelerden ziyade onun bir varoluş biçimi olan edimini sever. Kalede kalmaya karar verdikten sonraki duyguları, onun bu bağlamda bir homo viator olduğunu gösterir.

Drogo'nun yazgısı gereği içinde bulunduğu kale, ontolojisi itibariyle kahramanca bir umudun gerçekleşmesi için gereken şartları vermekten uzak olduğundan derin bir paradoksu doğurur. Neredeyse yüzyıldır kale aynı varlığıyla bu sınırı beklemektedir ve hiçbir şey olmamıştır. Bu ortamdaki umut, ister istemez sessiz bekleyişten başka bir şey değildir. Gerçekleşmesi için eyleme geçilemeyen bir umuttur. Beklemenin doğurduğu bu edilgenlik, roman kahramanlarının hepsini iradesiz varlıklar seviyesine düşürmüştür. Fromm, bu tür bir umudun kendi içinde çelişkili bir anlam taşıdığını düşünür. Böyle bir umudu, atlama anı geldiğinde sıçrayacak olan çömelik bir kaplana benzetir (2012: 23). Marcel de "Ontolojik Muamma Üzerine" isimli denemesinde "durgun (âtıl) umut" adını verdiği bu umut biçiminin kendi içinde çelişki taşıdığını düşünür. Ona göre umut bir tür kayıtsız, kaygısız bekleyiş değildir; o eylemi alttan alta destekler ya da onun önünden koşar fakat eylem tükendiğinde alçalır ve yiter gider (2001: 76). 
Drogo'yla birlikte edilgen bir umudun içinde nefes alan diğer bir roman kahramanı kale komutanı Albay Filimore'dur. At olayından kısa bir süre sonra, kuzey sınırında bu sefer daha belirgin hareketlenmeler görülür. Kaleye doğru hareket eden ve gerçekten askere benzeyen küçük siyah noktalardan oluşan çizgi, kaç yıldır bu kalede olduğunu unutan Filimore'u heyecanlandırmaz. Kaledeki askerlerin nöbetçi subayın emriyle ateşlenen uyarı topuyla büyük bir heyecan duymalarına rağmen, Filimore yıllardır beklediği umudunu karşılamaya cesaret edemez, çünkü burada geçirdiği anlamsız ve tekdüze yıllar ona ihtiyatlı olmayı öğretmiştir. Aslında bu ihtiyat bir tür cesaretsizliktir; kaderiyle karşılaşmaktan duyduğu korkudan doğan cesaretsizlik. Filimore umudunun gerçekleşeceğine olan inancını kaybetmiştir. Yine de kuzey sınırında görülen askerlerin kaleye saldıracaklarına ve komutasındaki askerlerle yıllardır beklediği zamanın gelmiş olduğuna kendini inandırmaya çalışır. Bir iç çatışmaya dönüşen umudun gerçekleşmesi yönündeki inanç ve inançsızlık yüzünden bir türlü nasıl davranacağına karar veremez. Kısa bir süre sonra genelkurmay başkanından gelen mektupta, bu birliklerin Kuzey Krallığı'ndan gelen ve sadece sınır çizgisini belirlemeye çalışan birlikler olduğu anlaşılır.

Kaledekilerle beraber hem Filimore, hem de Drogo'nun kahramanlik umutlarının onların yaşamlarına eşlik eden ve onunla birlikte büyüyen bir yönü vardır. Bu durum umut ve inanç arasındaki ilişkiden kaynaklanır. Kale var olduğu müddetçe herkes aynı umudu taşıyacak ve ona inanmaya devam edecektir. Beklemek ve umut etmek onların yaşamlarının gizil bir gücüdür. Fromm, umut yokluğunun yaşamın olgusal ve gizil potansiyelini yok ettiğini söyler. Umut ise, yaşamın doğasında, insan ruhunun dinamiğinde var olan bir öğedir. Bu, yaşamın doğasını oluşturan bir başka öğe olan inanca yakından bağlıdır (2012: 27). Umut, inanca eşlik eden bir ruh hâlidir; umut olmaksızın inancın ayakta durması imkânsızdır (2012: 29). Bu inanç ütopik olmanın ötesinde belki imkânsızdır. Ancak bu imkânsızlık kaledekilerin yaşamsallıklarıyla paraleldir. Yani Drogo ve diğerleri nefes aldıkları müddetçe bu imkânsız umudu bekleyeceklerdir. Umutları imkân dâhilinde olduğu an ise onlar hayatta olmayacaklardır. Drogo'nun sonu bu imkânsızlıkla aynı biçimde gelişir. Kuzey Krallığı'nın sınıra bir yol inşa etmeye başlaması, onun tükenmekte olan umutlarını yeniden canlandırır. Otuz yıldır beklediği umudun gerçekleşme olanağı ortaya çıktığ1 anda hastalanır ve kaleden gönderilirken yolda konakladıkları bir handa ölümü beklemeye başlar.

Tatar Çölünde olduğu gibi Gizli Emir de umut ve beklemenin varoluşsal problem olarak ele alındığı bir romandır. Tatar Çölünde Drogo ve kaledekiler kuzeyden gelecek düşmanı beklerken, Gizli Emir'de kentte süren karmaşayı ortadan kaldıracak, AYOT'un uyguladığı sıkıyönetimi sonlandıracak gizli emir beklenir. Ancak roman kahramanları bu emrin nereden geleceğini, 
kimin tarafından gönderileceğini ve neler içereceğini bilmezler. Beklentinin ne zaman başladığı da belli değildir. Bastiani Kalesi'nin bir yazgı olarak öncesizliğinin umudun kaynağını belirsiz kıldığı gibi, Gizli Emir'de de adıverilmeyen kentte yaşayan insanların gizli emirle ilgili umutlarının ne zaman başladığı belli değildir. Romanın aydın ve sanatçı kişileri kendi aralarında yaptıkları toplantıların birinde bekleyişin zamansızlığı, umudun insanın varlık olma anıla birlikte başladığı vurgulanır: "Kaç kez toplanmışlar ve emrin gene gecikeceğini -ama bu gecikme hep iki ya da üç gün olarak düşünülürdü- anlayarak" dağılmışlar. "Bekleyiş çok uzun zamandır sürüp geldiği için de toplananlar boyuna değişmiş-ölenler olmuştu epey- ayrıca toplananların sayısı da yirmi ikiden altıya" düşmüştür (2011: 19).

Gizli Emir'de kaosa son vereceği düşünülen gizli emir, roman kahramanlarının hayata tutunduran tek umuttur. Ancak bu, onlar için arzulanan şeyin nesnesi olmaktan öte bir anlam taşımamaktadır. Daha doğrusu beklemek, bir edim olarak yazgının kabullenilmesi ve bu dünyada varoluşun bir biçimidir. Bekleyen-varlıklar olarak bütün kent halkı, aydınlardan okumuşlara, sıradan insanlardan AYOT yönetici ve memurlarına kadar herkes, kendi varlık bilinçlerini bu bekleme ve umut eylemi içinde tecrübe eder. Bu ontolojik durumda, umudun umut edene aşkın hâle geldiği görülür (Marcel: 1971:142). Marcel'in "varlığın ontolojik sırrı" olarak tanımladığı başka bir olgu veya duyguya bağlanma fikriyle açıklanabilir (Bayraktar 2014: 69). Gizli Emir'de romanın merkez kahramanı sayılabilecek Heykeltıraş Nizam, çeşitli vesilelerle sanatçılarla bir araya geldiğinden içinde bulundukları durumu yorumlarken, sanki bu ontolojik sırra işaret eder. Ona göre yaptıkları bütün eylem ve varoluşlarının anlamı gizli emre bağlanmışır. Resim ve heykel yapmayı, tiyatroda oynamayı hatta âşı olmayı bile gizli emrin belirtileri olarak gören Heykeltıraş Nizam "bize beklemekten başka bir hak verilmiş değildir" (2011: 201) diyerek umudun ve beklemenin varoluşun farkına varmak olduğunu savunur. İnsanların kendilerini "gizli emirle tanıtladıklarını” söylerken, bu varoluş biçimine vurgu yapar. Çünkü gizli emri beklemek, hayatın anlamı ya da anlamsızlı̆̆ıdır. Bütün davranı̧̧ ve eylemler onunla şekillenir; başka bir deyişle insanın varlıksal özelliği hâline gelir. İnsanın varlık durumu, dünyadaki oluş hâli sadece beklemektir: "Herkesin gizli emri beklediği günlerdi, bütün umutlar ona bağlanmıştı; bu yüzden ilişkiler, görevler, ödevler, düşler ve tasarılar, hepsi hepsi askıdaydi; bunların yerini sadece ve sadece beklemek almıştı" (2011: 182-183).

Bekleyen-varlık olarak insanın ontolojik sırrı, bir şeye bağlı olma biçiminde kendini gösterirken, bağlı olunan şeyin değil, ona ulaşmak için girişilen eylemin önemli olduğu bir düşünceye işaret eder. Gizli Emir in sanatçı kahramanlarından olan Aktör Bilâl'in kendi varlığıyla ilgili bilinci bu ontolojik sırrı açı̆̆a vuracak biçimde gelişmiştir. İnsanın varlık olarak ancak amaçlarla 
değerlendirilebileceğini düşünen Aktör Bilâl'e göre, insan sadece dişsal bir varlıktır. Bu bakımdan sadece amaçlar ve beklediği şeylerle kendini gerçekleştirebilir. Bu yüzden o, "bekliyorsam varım” derken kendi varlığının ontolojik sırrına ulaşmış bir bilince sahip olduğunu ortaya koyar.

Beklemenin insanın varoluşsal anlamını belirleyen iki yönü vardır: umut ve umutsuzluk. Romanın Ressam Macit'le ilgili bölümünde, bekleme ve umut etme üzerine tartışlırken umut ve umutsuzluğun insan varoluşunun iki yönü olduğu dile getirilir: "Gizli emrin kendisi mi daha önemlidir, yoksa onu beklemek mi?” (2011: 198). Bu, kendini gerçekleştirme deneyimine yönelik metafiziksel bir duyuşa sahip olmanın bilinciyle ilişkili bir durumdur. Marcel bu duyuşu metafiziksel aşkın varlık olarak Mutlak Varlık'la/ Tanrı'yla ilişkilendirir. Onun felsefesinde umudun fenomenolojisi, insan varoluşunun tam kalbindeki mutlak öğeyi işaret eder. Dolayısıyla umut, sahip olduğu her şeyi kendisine borçlu olduğu ve ona karşı bir koşul öne sürmeyeceğinin bilincinde olan bir canlının, Mutlak Varlık’a bir yanıtı olarak düşünülmüştür (Koç 2014: 93). Gizli Emir'de ise bekleme ve umudun yöneldiği metafiziksel aşkın varlık, bizzat insanın kendisiyle ve kendini inşa etme süreciyle ilgilidir. Bekleme ve umut bu sürece tanıklık etme anlamına gelmektedir. İnsanın varlık bilinci yine insanın kendine içkin durumudur. Umut ve bekleme bu duruma giden yoldur sadece. Dolayısıyla dışa yönelen değil, içe yönelmesi gereken bir bilince işaret eder. Heykeltıraş Nizam'ın yaklaşımı da bunu destekleyecek niteliktedir. Ona göre gizli emri aramak boşunadır, "çünkü aramak, onu uzağımızda düşünmek demektir" (2011: 204). Önemli olan onu aramaya çalışmak değil, onu düşlemektir.

Gizli Emir'de beklemenin karşılı̆̆1 olarak düşünülen umut, Tatar Çölü̉nden farklı olarak bireyin kendi varlığını ve bilincini algılama, dünyayla kurduğu ilişki biçimine göre farklılık gösterir. Bastiani Kalesi'nin sakinleri genel olarak kuzeyden gelecek düşmana karşı savaşmayı umut ederken, Gizli Emir' in kahramanları umudu kendi bireysellikleri bağlamında değerlendirir. Romanın girişindeki sahnede abdesthane bekçisi, kundura boyacısına gizli emrin belki de belediye abdesthanelerinin önünde kundura boyanmasını yasak edeceğini söyler (2011: 2). Kahvehane sahibi, kentteki anarşi yüzünden sürekli tahrip edilen dükkânını kapatmamak için gizli emri bekler. Gazetenin idare müdürü gizli emirde maaşlarına yapılacak zamla ilgili haber bekler (2011: 14). Romanın en önemli figürü Heykeltıraş Nizam için gizli emir ve bekleme, "varoluşun doğrulanması" olarak önemlidir (Doğan 2012: 200). Nizam’ın karısı Kutlu için gizli emir, bireyselliğini yaşayacağı ve bazı toplumsal engellerden, aile bağlarından kurtulacağ 1 yönündeki arzusunu karşılar. Başyazar Kutsi ise gizli emri kendini önemli saymanın aracı olarak görür. Bu emrin ilk önce ona geleceğine inanan Kutsi için onu beklemek önemli bir adam olma düşünün kurulduğu bir edimdir. 
Gizli Emir'in beklemeyen/bekleyemeyen tek kahramanı Ressam Macit'tir. Romanın geriye dönüş tekniğiyle kurgulanan beşinci bölümünde üzerinde durulan bu kişi, yaşanan kaos ve belirsizlik ortamından umutsuzluğa düşüp evine kapanmı̧̧ ve resim yapmayı bırakmıştır. Karısı Nigâr tarafından "zavallı biri” olarak nitelendirilen Macit, umuda karşı umutsuzluğun, beklemeye karş1 vazgeçmenin simgesidir. Yaşarken hissedilmeyen, ancak öldükten sonra aşkın ve sevginin simgesine dönüşen bir kişi olarak önem kazanmıştır (Doğan 2012: 202). Gizli Emir, umudun metafiziksel bir duyuş olarak insanın peşinde olduğu, kendi olma yolundaki rolünün başarıya ulaşıp ulaşamayacağ1 sorusunu askıda birakır. Yazar bu konuda bir sonuca varmadan romanı bitirir. Tatar Çölünde Drogo'nun, beklediği umut yaklaştığında onu karşılayacak gücü kalmamıştır; Gizli Emir'de ise insanın bu dünyadaki yolculuğunun umut etmesinden ötürü asla sonlanmayacağı ima edilir.

\section{Umutsuzluğun Büyük Hazzı}

Umutsuzluk diyalektik olarak umudu belirleyen tek insanî olgudur, çünkü insanın dünya içindeki varlığını belirleyen şartların, umutsuzluğu doğuran nedenler olarak umudu var etmesi söz konusudur. Başka bir deyişle umutsuzluk, umudu var eden tek olgudur. Umut ve umutsuzluk arasındaki bu diyalektik ilişki, aynı zamanda insan bilincinin bunu algılaması bağlamında değer kazanır. Kierkegaard bu bilinci, insanın kendi varoluşunun farkında oluş durumuyla ilişkilendirir. Bu yüzden de tıpkı umut gibi umutsuzluğu da bir varoluş biçimi olarak görür. Ona göre umutsuzluk, yalnızca soyut bir fikir olarak ele alındığında büyük bir avantaj olarak düşünülmelidir. Umutsuzluğun acısını çekmek zorunda kalmak, insanı hayvanın üstüne yerleştirir ve bu tinselliğimizin yüceliğinin veya sonsuz dikeyliğimizin işareti olan dikey yürüyüşten çok farklı bir biçimde bizi ayırt eden bir gelişmedir (2007: 23). İnsanın dünyasallığıyla belirlenen varoluş biçiminin dünyayı algılama yolunda geliştirdiği yönelimin sonucu olarak ortaya çıkan umutsuzluk dünyayı açığa vurur. Jean-Paul Sartre'ın, varlığın dünyayı anlama konusunda seçilen amaca göre, dünyanın kendini göstermesi olarak yorumladığı bu yönelimde, umut olarak kendini gösteren, dünyayı aydınlatan amaç olurken, umutsuzluk dünyanın henüz varolmayan durumudur (2010: 601). Tatar Çölü ve Gizli Emir'de umutsuzluk, kahramanların yaşadığı varoluşsal bir deneyim olarak umudu doğuran ve belirleyen temel bir insanî olgu olarak belirir. Drogo ve kalenin diğer sakinleri ile Gizli Emir'de adı verilmeyen kentte yaşayanlar, ulaşmak istedikleri umutların gerçekleşmesi için bilincinde olmadıkları bir umutsuzluğun içinde yaşarlar. Çünkü umutsuzluk onların varlık biçimidir. Kierkegaard umutsuzluğun bu çeşidini, umutsuz olmamaktan çok, umutsuz- 
luğun bilincinde olmamaktan doğan bir umutsuzluk biçimi olarak değerlendirir (2007: 32).

Drogo, düşmanı beklerken her defasında hayal kırıklı̆̆ına uğradığı hâlde umudunu canlı tutmaya çalı̧ır; bu aslında onun umutsuz bekleyişidir. Ancak Drogo, bekleyişinin umutsuz bir çaba olduğunu fark edemeyecek hâldedir. Bu durum, ruhsal çöküntüye sebep olur. Kalede kalmakla şehre dönmek arasında yaptığı karşılaştırmada, kalenin yüzyıllık tarihini bilmesine rağmen burada kalmayı tercih etmesi, umudun doğurduğu bir umutsuzluk hâlidir:

Şehrin hayali Drogo'nun aklından geçti, solgun bir hayaldi bu; yağmurun altındaki gürültülü sokaklar, alçıdan heykeller, kışlaların rutubeti, can sıkıcı çanlar, yorgun ve bakımsız çehreler, sonsuz öğleden sonralar, tozdan grileşmiş tavanlar... Burada ise, tersine kalenin tepesinden uçup giden ve mucizevî alametler taşıyan bulutlarıyla koca bir dağ akşamı başliyordu. Ve Drogo, yazgısının kuzeyden yana, görünmeyen kuzeyden yana ağırlı̆̆ını koyduğunu hissetti. (2014: 69-70)

Drogo ve kaledekilerin bekleyişlerinin sonsuz ve pasif bir şekilde olması umutsuzluğu ortaya çıkarır. Bekleme, hiçbir atılım gerektirmeyen, kalenin alışılmış hayatını anlamlı kılan tek edimdir. Drogo için bu, yaşamsal ve hiçbir çaba gerektirmeyen bir hazdır. Kalenin burçlarından kuzey sınırına bakmak, çoğu zaman sisler içindeki sınır boyunca Tatar çölünde sıra dışı bir hareketi, bir karartıyı, bir ışığı aramak Drogo ve kalenin diğer sakinleri için hayatın tek hazzıdır. Bauman, bu şekilde sonuçsuz beklemenin ve bundan haz almanın göz korkutucu olduğu görüşündedir (2011: 112).

Gizli Emir'deki kahramanlar da aynı korkutucu beklemenin doğurduğu umutsuzluk içinde varoluşlarını tecrübe ederler. Kahramanlar sürekli bir gerilim hâli yaşarken, aslında umutsuzluğun bilincinde olmaktan uzaktırlar. Başta Heykeltıraş Nizam olmak üzere sanatçı ve yazar kahramanlardan oluşan grup, gizli emrin geleceğine dair umutlarını sürekli canlı tutar. Ancak umutsuz bir çile hâline gelen beklemenin, amaçsız bir çaba olduğunu kimse itiraf edemez. Bu kahramanlar içinde umutsuzluğunun farkına varan tek kişi Ressam Macit'tir. Macit'in umutsuzluğu, öldükten sonra karısı Nigâr'ın bakış açısından verilir. Nigâr, onun umutsuzluk duygusuna kapıldığı anlarda resim yapmayı bıraktığını, eve kapanıp günlerce yatağından çıkmadığını hatırlar. Bazen de kentten ayrılıp günlerce parklarda ve ormanlarda vakit geçiren Macit'in ruh hâli Drogo'nun yaşadığıyla benzerlik taşımaktadır. Marcel'e göre umutsuzluk bir tür teslim oluş hâlidir. Bir yazgıya teslim olup ona boyun eğmek insanın hakkında verilen kararı kabul etmesi demek değildir. Bu karar karşısında bilincin ve benliğin parçalara ayrılması, kaçınılmaz olan karşısında mücadeleden vazgeçmektir (1951: 37). Bu durum, her iki romanda, umudun umutsuzluğa dönüşmesi şeklinde ortaya çıkar. 


\section{Sonuç}

Buzatti'nin Tatar Çölü ve Anday'ın Gizli Emir adlı romanları, insanın dünyadaki varoluşunu umut ve umutsuzluk paradoksu içinde ele alır. Ancak bu, tezat teşkil eden olguların yarattığı bir paradoks değildir. İki romanda da umut ve umutsuzluk birbirlerini var eden ve besleyen iki varoluş biçimi olarak ele alınır. Bunların doğurduğu eylem ise beklemedir ve eylemin nesnesine değil kendisine yönelen bir varlık durumunu simgeler. Roman kahramanları için önemli olan, beklemenin yöneldiği arzu değil, bizzat edimin kendine içkin olan özüdür. Bu, kahramanların varlıklarını sürekli bir bekleme edimi içinde tecrübe etmelerine neden olur. Burada ön plâna çıan, insanın sürekli umut ve umutsuzluk arasında kalışının doğurduğu gerilimlerin evrensel bir insan gerçekliği olduğu fikridir. Varoluşçu düşünce bağlamında umut ve umutsuzluk, insanın bu dünyadaki varlık biçimidir ve bunun algılanması, varlığına dönük bilinçli veya bilinçsiz bir tasarımdır. İki romanda da insanın bu anlamdaki varlık bilinci, onun dünyasallığı bağlamında ele alınmıştır. $T a-$ tar Çölünnde bir kale, Gizli Emir'de ise adı verilmeyen kent, insanın varoluş şartlarını ve beklemenin anlamını/anlamsızlığını belirleyen mekânlar olarak roman kahramanlarının yazgılarını simgeler. 


\section{Kaynaklar}

Anday, Melih Cevdet (2011). Gizli Emir, İstanbul: Everest Yayınları.

Bauman, Zygmunt (2011). Postmodern Etik, Çev. Alev Türker, İstanbul: Ayrıntı Yayınları.

Bayraktar, Fulya (2014). Bağlanma Hürriyeti-Bir Gabriel Marcel Okuması, Ankara: Aktif Düşünce Yayınları.

Bloch, Ernst (2013). Umut İlkesi, Çev. Tanıl Bora, İstanbul: İletişim Yayınları.

Buzatti, Dino (2014). Tatar Çölü, Çev. Hülya Tufan, İstanbul: İletişim Yayınları.

Çilingir, Lokman (2003). Umut Felsefesi, Ankara: Elis Yayınları.

Çüçen, A. Kadir (2012). Martin Heidegger: Varlık ve Zaman, İstanbul: Sentez Yayınlari.

Doğan, Mehmet Can (2012). Melib Cevdet Anday'ın Romancılı̆̆ı, Ankara: Kurgan Edebiyat Yayınları.

Fromm, Erich (2012). Umut Devrimi, Çev. Şemsa Yeğin, İstanbul: Payel Yayınları.

Gasset, Jose Ortega y (2011). İnsan ve Herkes, Çev. Neyyire Gül Işı, İstanbul: Metis Yayınları.

Heidegger, Martin (2011a). Olmaya Bırakılmışlık, Çev. Mesut Keskin, İstanbul: Avesta Yayınları.

— (2011b). Varlık ve Zaman, Çev. Kaan H. Ökten, İstanbul: Agora Kitaplığı.

Kierkegaard, Søren (2007). Ölümcül Hastalık Umutsuzluk, Çev. M. Mukadder Yakupoğlu, Ankara: Doğu-Batı Yayınları.

Koç, Emel (2014). Gabriel Marcel Üstüne, Ankara: Pegem Akademi Yayınları.

Marcel, Gabriel (1951). Homo Viator: Introduction to a Metaphysic of Hope, Çev. Emma Craufurd, Chicago: Henry Regnery Company.

— (1971). The Existential Background of Human Dignity, Massachusetts: Harvard Univesty Press.

— (2001). “Ontolojik Muamma Üzerine”, Metafizik Nedir?, Çev. Ahmet Aydoğan, İstanbul: Birey Yayınları.

Nietzsche, Friedrich (2010). İnsanca, Pek İnsanca, Çev. Cemal Atila, İstanbul: Say Yayınlar1.

Sartre, Jean-Paul (2010). Varlık ve Hiçlik, Çev. Turan Ilgaz ve Gaye Çankaya Eksen, İstanbul: İthaki Yayınları.

Tanrıbilir, Esra (2012). “Tatar Çölü: Beklerken Kaçırılan Zamanın Zamansız Romanı", Roman Kahramanlar 12, s.44-45.

Y1lmaz, Sibel (2011). "Yalnızlık Kalesinde Bir Kader Sürgünü: Giovanni Drogo", Ayraç 23, s.30-31. 


\title{
ABSTRACT \\ The Paradox of Hope and Hopelessness as an Existence Form in Tatar Çölï and Gizli Emir
}

\begin{abstract}
Although Dino Buzatti's Tatar Çölü and Melih Cevdet Anday's Gizli Emir are products of different languages and literatures, they can be regarded as texts that handle existential situation of human being in the world in the context of universal attributes of hope and hopelessness. While hope is presented in these two novels as the basic emotion that lead all the actions of human being in the world, it is pointed out that this emotion specify hopelessness in a dialectical way. In this sense, novelists who try to emphasize that hope and hopelessness paradoxically constitute the two sides of human being's existence, represent the lives of novel characters within the frame of tension which is designated by this paradox. This tension is visible in "waiting" action. The novelists remark that the action itself is more important than whether the hope that action gear occurs or not, and they imply that the existence of human being in this world is related to their attitudes they present about that action. Buzatti and Anday, who think that a human being who can see the "waiting" as a source of existential problem can reach his or her own sense of existence, have tried to handle the subject in a philosophical dimension within the possibilities of the novel genre.
\end{abstract}

Keywords: Tatar Çölü, Gizli Emir, existence, hope, hopelessness, waiting 